\title{
Pengaruh Label Halal dan Bonus dalam Kemasan terhadap Keputusan Pembelian pada Produk Kinder Joy pada Masyarakat Kota Langsa
}

\author{
Tengku Putri Lindung Bulan \\ Fakultas Ekonomi, Universitas Samudra \\ e-mail: tengkuputri@unsam.ac.id \\ Khairul Fazrin \\ Fakultas Ekonomi, Universitas Samudra
}

\begin{abstract}
Abstrak
Penelitian ini bertujuan untuk mengetahui pengaruh label halal dan bonus dalam kemasan secara parsial dan secara simultan terhadap keputusan pembelian pada produk Kinder Joy pada masyarakat Kota Langsa. Berdasarkan hasil uji $t$ variabel label halal dan bouns dalam kemasan berpengaruh signifikan terhadap keputusan pembelian pada produk Kinder Joy pada masyarakat Kota Langsa. Hasil uji $F$, secara simultan label halal dan bonus dalam kemasan berpengaruh signifikan terhadap keputusan pembelianpada produk Kinder Joy pada masyarakat Kota Langsa..
\end{abstract}

Kata Kunci: Label Halal, Bonus dalam Kemasan dan Keputusan Pembelian.

\section{PENDAHULUAN}

Saat diberlakukannya AFTA (Asean Free Trade Agreement) pada tahun 2015 sebagai bentuk dari trend globalisasi di abad ini, membuat arus ekspor-impor perdagangan antar negara-negara di wilayah tersebut semakin tinggi dan tanpa batas. Jauh sebelum itu juga telah berlaku perdagangan global yang sangat intensif yang juga membuat batas antar negara di dunia hampir tidak ada.Konsumen pada akhirnya dihadapkan kepada banyaknya pilihan produk, baik yang lokal atau impor, mahal ataupun murah. Hal ini berdampak kepada proses keputusan pembelian konsumen. Di dalam prosesnya, setiap konsumen dipengaruhi oleh banyak faktor yang akan menentukan keputusan pembeliannya. Dan faktor budaya biasanya memiliki faktor yang cukup dominan karena dia diajarkan secara turun temurun di dalam kehidupan sosial di setiap daerah sehingga melekat erat di dalam diri setiap individu.
Sementara itu, label menjadi salah satu faktor yang sangat penting di dalam pemasaran sebuah produk. Yang termasuk label seperti merek, logo ISO, informasi tentang kebaikan suatu produk, komposisi, dan label halal. Bagi orang Islam, kaidah halal dan haram adalah hal terpenting dan mendasar.Halal berarti segala sesuatu yang diperbolehkan untuk digunakan, dan haram adalah sesuatu yang tidak diperbolehkan untuk digunakan. Mengingat jumlah segmen pasar islam ini adalah salah satu pasar terbesar di dunia, seperti yang dilansir oleh media cetak dan online Republika, yang jumlahnya mencapai sekitar 1,8 miliar, membuat pasar ini sebagai pasar yang menarik bagi para pemasar, baik lokal maupun internasional.

Aturan halal ini dapat dijadikan kampanye pemasaran yang efektif bagi para pebisnis yang menyasar segmen ini.Sehingga pelabelan halal pada setiap produk yang beredar sudah menjadi suatu keharusan. 
Dalam penelitian (Bulan, 2016) tentang pengaruh labelisasi halal terhadap keputusan pembelian produk sosis di kota Kuala Simpang memperlihatkan terdapat pengaruh signifikan. Hal ini sejalan dengan yang telah dilakukan oleh perusahaan kosmetik lokal, Wardah, yang memilih kampanye pencitraan merek alat-alat kosmetiknya dengan "alat kosmetik yang halal".Langsung saja merek ini melejit menjadi pesaing bagi perusahaanperusahaan kosmetik besar yang telah lama ada, mengingat memang jumlah segmen pasar ini sangat besar.

Faktanya, di pasar Kota Langsa terdapat beberapa merek, khususnya produk pangan, yang tidak mencantumkan label halal pada kemasan produknya. Termasuk di dalamnya adalah Kinder Joy, salah satu merek produk makanan wafer coklat berbentuk bola dengan tambahan krim susu coklat dengan kemasan berbentuk telur. Selain tidak mencantumkan label halal pada kemasannya, produk asal Itali yang telah beroperasi selama lebih dari 40 tahun ini (www.kinder.me, 2017) juga tidak terdaftar di database online MUI yang dapat diakses di www.halalmui.org/pencarian_produk_halal.

Padahal Propinsi Aceh telah dideklarasikan sebagai daerah pariwisata halal unggulan oleh Menteri Pariwisata RI, Arief Yahya, pada tanggal 19 September 2016. Seperti yang dilansir oleh media cetak Online lokal Aceh, Serambi, Arief Yahya menegaskan untuk mendukung pencitraan daerah pariwisata halal tersebut, sertifikasi halal pada produk makanan, restoran, dan hotel mutlak diperlukan. Yang membuat produk ini menarik adalah mereka menyelipkan mainan gratisan dengan beragam bentuk yang menarik di dalam setiap kemasan produk mereka. Ditambah lagi, produk Kinder Joy ini selalu diletakkan di meja kasir di tokotoko pengecer di Kota Langsa.Dan setelah peneliti melakukan survei awal terhadap 15 orang konsumen Kinder Joy, mereka mengatakan bahwa produk ini cukup diminati dan sering dibeli. Namun konsumen hanya tertarik pada bonus mainan dalam kemasan daripada makanan dari produk Kinder Joy itu sendiri.
Bonus dalam kemasan yang diberikan Kinder Joy ini memungkinkan para pengunjung toko menjadi tertarik untuk membelinya. Apalagi bentuk bonus yang diberikan sangat sesuai dengan pasar sasarannya, yaitu pasar anak-anak. Hal ini sejalan dengan penelitian yang telah dilakukan oleh Prihastama, bahwa bentuk promosi penjualan untuk meningkatkan penjualan di toko adalah program kupon, diskon harga, sampel gratis, penataan display, dan bonus dalam kemasan (Ndubisi dan Moi dalam Prihastama, 2016).

Hal ini yang membuat peneliti tertarik untuk melakukan penelitian yang berhubungan dengan fenomena ini, karena penelitian yang telah pernah dilakukan tersebut bertempat di luar Aceh. Sehingga diharapkan penelitian ini dapat menjadi masukan bagi perusahaan-perusahaan, baik lokal maupun internasional, dalam menentukan strategi pemasarannya dan juga diharapkan dapat memberikan informasi kepada masyarakat tentang kehalalan suatu produk yang akan dibeli dan strategi promosi bonus dalam kemasan, khususnya yang ada di Kota Langsa. Penelitian ini dilakukan dengan tujuan untuk mengetahui pengaruh label halal dan bonus dalam kemasan secara parsial dan secara simultan terhadap keputusan pembelian pada produk Kinder Joy pada masyarakat Kota Langsa.

\section{Label}

Permasalahan label sebenarnya termasuk ke dalam ruang lingkup ilmu pemasaran. Karena label memegang peranan yang sangat penting dalam strategi pemasaran. Label bisa membawa nama merek saja, atau sejumlah besar informasi yang berkaitan dengan produk (Kotlerdan Keller, 2009). Label biasanya terbuat dari kertas, laminasi kertas, atau film plastik dengan atau tanpa tambahan perekat, label dapat mencakup keseluruhan kemasan atau hanya setempat saja, dapat dipotong dalam berbagai bentuk yang beragam untuk menyesuaikan bentuk kemasannya (Krasovec dan Klimchuk dalam Utami, 2013).

Boone dan Kurtz (2010) menyatakan bahwa sebuah label dapat membawa 
namamerek atau simbol, nama dan alamat dari pabrik yang memproduksi, informasi tentang komposisi dan ukuran produk, dan cara penggunaan yang direkomendasikan. Pelabelan yang benar dapat berperan sangat penting dalam menarik perhatian konsumen dan mendorong mereka untuk membeli.

Menurut Kotler dan Keller (2009), label mempunyai fungsi sebagai berikut:

1. Pengenal, yaitu label sebagai identitas pengenal produk.

2. Pemeringkat, yaitu label dapat menunjukkan kelas produk. Seperti pada produk buah peach yang diberi label $\mathrm{A}$, $\mathrm{B}, \mathrm{C}$ dan seterusnya.

3. Penjelas, yaitu label berfungsi untuk menjelaskan tentang produsen, lokasi produksi, waktu produksi, komposisi produk, dan cara penggunaan produk.

4. Promosi, yaitu melalui grafis yang menarik.

\section{Label Halal}

Qardhawi (Ath-Thawil, 2016), mendefinisikan halal sebagai segala perkara yang dibolehkan, tidak mengandung transaksi yang terlarang secara syariat, dan telah dilegitimasi oleh syariat untuk memberlangsungkan perkara tersebut.Di dalam Undang-Undang Nomor 33 Tahun 2014 Tentang Jaminan Produk Halal dijelaskan bahwa produk halal adalah produk yang telah dinyatakan halal sesuai dengan syariat Islam.

Dalam Peraturan Pemerintah Nomor 69 Tahun 1999 Tentang Label dan Iklan Pangan, label pangan adalah setiap keterangan mengenai pangan yang berbentuk gambar, tulisan, kombinasi keduanya, atau bentuk lain yang disertakan pada pangan, dimasukkan kedalam, ditempelkan pada, atau merupakan bagian kemasan pangan, yang selanjutnya dalam peraturan pemerintah ini disebut label. Sedangkan di dalam Undang-Undang Nomor 33 Tahun 2014 Tentang Jaminan Produk Halal menyebutkan bahwa yang dimaksud dengan label halal adalah tanda kehalalan suatu produk.

Produk halal kini bukan lagi sematamata isu agama Islam, tetapi sudah menjadi isu dan perdagangan saat ini. Jaminan halal sebuah produk sudah menjadi simbol global bahwa produk yang bersangkutan terjamin mutunya. Hal ini karena pasar umat Islam adalah pasar yang sangat menggiurkan mengingat jumlah umat Islam saat ini sebesar 1,8 miliar secara global (khazanah.republika.co.id, 2016).

\section{Proses Labelisasi Halal}

Setiap perusahaan yang telah mencantumkan label halal pada setiap kemasan produknya harus telah memiliki sertifikat halal dari LPPOM MUI. Namun sebelum sertifikat halal diberikan kepada perusahaan, ada beberapa proses yang harus dilalui agar sertifikat halal dapat diberikan. Bagi perusahaan yang ingin memperoleh sertifikat halal LPPOM MUI, baik industri pengolahan (pangan, obat, kosmetika), Rumah Potong Hewan (RPH), dan restoran/katering/dapur, harus melakukan pendaftaran sertifikasi halal dan memenuhi persyaratan sertifikasi halal. Berikut ini adalah tahapan yang dilewati perusahaan yang akan mendaftar proses sertifikasi halal (www.halalmui.org, 2017):

1. Memahami persyaratan sertifikasi halal dan mengikuti pelatihan $\mathrm{SJH}$

Perusahaan harus memahami persyaratan sertifikasi halal yang tercantum dalam HAS 23000. Selain itu, perusahaan juga harus mengikuti pelatihan SJH (Sistem Jaminan Halal) yang diadakan LPPOM MUI, baik berupa pelatihan reguler maupun pelatihan online (e-training).

2. Menerapkan Sistem Jaminan Halal (SJH)

Perusahaan harus menerapkan SJH sebelum melakukan pendaftaran sertifikasi halal, antara lain: penetapan kebijakan halal, penetapan Tim Manajemen Halal, pembuatan Manual $\mathrm{SJH}$, pelaksanaan pelatihan, penyiapan prosedur terkait $\mathrm{SJH}$, pelaksanaan internal audit dan kaji ulang manajemen.

3. Menyiapkan dokumen sertifikasi halal Perusahaan harus menyiapkan dokumen yang diperlukan untuk sertifikasi halal, antara lain: daftar produk, daftar bahan dan dokumen bahan, daftar penyembelih (khusus RPH), matriks produk, Manual $\mathrm{SJH}$, diagram alir proses, daftar alamat 
fasilitas produksi, bukti sosialisasi kebijakan halal, bukti pelatihan internal dan bukti audit internal.

4. Melakukan pendaftaran sertifikasi halal (upload data)

Pendaftaran sertifikasi halal dilakukan secara online di sistem Cerol (Certification Online) melalui website www.e-lppommui.org. Perusahaan harus membaca user manual Cerol terlebih dahulu untuk memahami prosedur sertifikasi halal. Perusahaan harus melakukan upload data sertifikasi sampai selesai, baru dapat diproses oleh LPPOM MUI.

5. Melakukan monitoring pre audit dan pembayaran akad sertifikasi

Setelah melakukan upload data sertifikasi, perusahaan harus melakukan monitoring pre audit dan pembayaran akad sertifikasi. Monitoring pre audit disarankan dilakukan setiap hari untuk mengetahui adanya ketidaksesuaian pada hasil pre audit.Pembayaran akad sertifikasi dilakukan dengan mengunduh akad di Cerol, membayar biaya akad dan menandatangani akad, untuk kemudian melakukan pembayaran di Cerol dan disetujui oleh Bendahara LPPOM MUI.

f. Pelaksanaan audit

Audit dapat dilaksanakan apabila perusahaan sudah lolos pre audit dan akad sudah disetujui. Audit dilaksanakan di semua fasilitas yang berkaitan dengan produk yang disertifikasi.

g. Melakukan monitoring pasca audit

Setelah melakukan upload data sertifikasi, perusahaan harus melakukan monitoring pasca audit. Monitoring pasca audit disarankan dilakukan setiap hari untuk mengetahui adanya ketidaksesuaian pada hasil audit, dan jika terdapat ketidaksesuaian agar dilakukan perbaikan.

h. Memperoleh Sertifikat halal

Perusahaan dapat mengunduh Sertifikat halal dalam bentuk softcopy di Cerol. Sertifikat halal yang asli dapat diambil di kantor LPPOM MUI Jakarta dan dapat juga dikirim ke alamat perusahaan. Sertifikat halal berlaku selama 2 (dua) tahun.
Dalam rentang waktu tersebut, produsen harus bisa menjamin kehalalan produknya. Proses penjaminannya dengan cara pengangkatan Auditor Halal Internal untuk memeriksa dan mengevaluasi Sistem Jaminan Halal (Halal Assurance System) di dalam perusahaan. Auditor Halal tersebut disyaratkan harus beragama Islam dan berasal dari bagian terkait dengan produksi halal. Hasil audit oleh auditor ini dilaporkan kepada LPPOM MUI secara periodik (enam bulan sekali) dan bila diperlukan LPPOM MUI melakukan inspeksi mendadak dengan membawa surat tugas.

\section{Manfaat Labelisasi Halal}

Label halal pada kemasan setiap produk sangat penting bagi konsumen umat Islam. Sertifikasi Halal MUI pada produk pangan, obat-obat, kosmetika dan produk lainnya dilakukan untuk memberikan kepastian status kehalalan, sehingga dapat menenteramkan batin konsumen dalam mengkonsumsinya (www.halalmui.org, 2017).

Selain pertimbangan moral yang harus terjaga pada umat Islam, label halal juga dapat dijadikan sebagai salah satu senjata ampuh dalam strategi pemasaran bagi setiap perusahaan di zaman ini. Mengingat umat Islam adalah salah satu pasar terbesar di dunia, maka produk halal menjadi faktor penentu pada strategi produk di dalam bauran pemasarannya, sehingga pasar umat Islam menjadi lebih tertarik kepada produk-produk halal.

\section{Indikator Label Halal}

Menurut Peraturan Pemerintah Nomor

69 Tahun 1999 (dalam Utami, 2013), indikator label halal adalah:

1. Gambar

Merupakan hasil dari tiruan berupa bentuk atau pola (hewan, orang, tumbuhan dsb.) dibuat dengan coretan alat tulis.

2. Tulisan

Merupakan hasil dari menulis yang diharapkan bisa untuk dibaca.

3. Kombinasi Gambar dan Tulisan 
Merupakan gabungan antara hasil gambar dan hasil tulisan yang dijadikan menjadi satu bagian.

4. Menempel pada Kemasan

Dapat diartikan sebagai sesuatu yang melekat, (dengan sengaja atau tidak sengaja) pada kemasan (pelindung suatu produk).

\section{Bauran Promosi}

Dalam melakukan kegiatan promosi secara optimal, maka dapat dilakukan menggunakan bauran promosi. Terdapat delapan model bauran promosi (Kotler dan Keller, 2009), yaitu:

1. Iklan, semua bentuk berbayar dari presentasi nonpersonal.

2. Promosi Penjualan, berbagai insentif jangka pendek untuk mendorong percobaan atau pembelian produk atau jasa.

3. Acara dan Pengalaman, kegiatan dan program yang disponsori perusahaan yang dirancang untuk menciptakan interaksi yang berhubungan dengan merek tertentu.

4. Hubungan Masyarakat dan Publisitas, beragam program yang dirancang untuk mempromosikan atau melindungi citra perusahaan atau produk individunya.

5. Pemasaran Langsung, penggunaan surat, telepon, faksimail, email, atau internet untuk berkomunikasi secara langsung atau meminta respon atau dialog dari pelanggan dan prospek tertentu.

6. Pemasaran Interaktif, kegiatan dan program online yang dirancang untuk melibatkan pelanggan atau prospek dan secara langsung atau tidak langsung meningkatkan kesadaran, memperbaiki citra, atau menciptakan penjualan.

7. Pemasaran Dari Mulut Ke Mulut, komunikasi lisan, tertulis, dan elektronik antar masyarakat yang berhubungan dengan keunggulan atau pengalaman membeli atau menggunakan produk.

8. Penjualan Personal, interaksi tatap muka dengan satu atau lebih pembeli prospektif untuk tujuan melakukan presentasi, menjawab pertanyaan, dan pengadaan pesanan.

\section{Bonus dalam Kemasan}

Ndubisi dan Moi (dalam Prihastama, 2016) menjelaskan bahwa bentuk promosi penjualan yang dapat meningkatkan penjualan adalah program kupon, diskon harga, sampel gratis, bonus dalam kemasan, dan in-store display. Bonus dalam kemasan termasuk alat promosi penjualan yang paling banyak digunakan, baik dalam penjualan online maupun offline (Chen, Marmorstein, Tsiro, \& Rao,; Dawson \& Kim (dalam Prihastama, 2016)

Belch \&Belch (dalam Prihastama, 2016) menjelaskan bahwa bonus dalam kemasan menawarkan konsumen sebuah muatan ekstra dari sebuah produk dengan harga normal. Sedangkan menurut Mishra \& Mishra (dalam Prihastama, 2016), bonus dalam kemasan merupakan strategi promosi penjualan berbasis kuantitas dimana pelanggan ditawarkan produk dengan kuantitas lebih dengan harga yang sama.

Shimp (dalam Prihastama, 2016) mendefinisikan bonus dalam kemasan adalah tambahan produk dari perusahaan untuk diberikan kepada konsumen dengan harga yang sama. Selanjutnya menurut Harper (dalam prihastama, 2016), bonus dalam kemasan adalah upaya untuk menarik pembelian dengan menawarkan produk atau jasa gratis dengan harga yang sudah dikurangi untuk mendorong pembelian produk lain.

\section{Indikator Bonus dalam Kemasan}

Bonus dalam kemasan diukur dengan menggunakan indikator-indikator (Belch \&Belch dalam Prihastama, 2016) berikut:

1. Memberikan penawaran dengan manfaat ekstra.

2. Strategi bertahan terhadap promosi produk baru dari pesaing.

3. Menghasilkan pesanan penjualan yang lebih besar.

\section{Keputusan Pembelian}

Keputusan pembelian konsumen adalah membeli merek yang paling disukai dari berbagai alternatif yang ada (Kotler dan Armstrong, 2008). Mowen dan Minor (dalam Utami, 2013) menyatakan bahwa perspektif 
pengambilan keputusan menggambarkan seorang konsumen sedang melakukan serangkaian langkah-langkah tertentu pada saat melakukan pembelian.

Setiap produk memiliki tingkat keterlibatan yang berbeda dalam proses pengambilan keputusan pembelian yang sama. Boone \& Kurtz (2010) membagi tingkat keterlibatan ini kepada dua tingkat, yang pertama produk dengan keterlibatan tingkat tinggi, yaitu produk-produk yang memberikan dampak ekonomi dan sosial yang besar bagi konsumennya. Membeli mobil, apartemen, atau memilih tempat kuliah adalah beberapa contoh bagi kategori produk ini.

Yang kedua adalah produk dengan keterlibatan tingkat rendah, yaitu produkproduk yang rutin dibeli dalam kehidupan sehari-hari dan tidak memberikan dampak yang besar bagi setiap konsumennya. Membeli suatu merek untuk jus jeruk kemasan, membeli permen adalah beberapa contoh yang sangat cocok untuk kategori produk ini.

\section{Faktor-Faktor yang Mempengaruhi Keputusan Pembelian}

Ada dua faktor yang mempengaruhi seorang konsumen dalam proses pengambilan keputusan pembelian, yaitu (Boone dan Kurtz, 2010):

1. Pengaruh dari dalam diri

a. Kebutuhan, yaitu ketidaksesuaian antara keadaan konsumen sebenarnya dengan keadaan yang diharapkan. Seseorang yang sadar bahwa ada kebutuhan untuk menghilangkan dahaganya, maka dia akan berusaha untuk memperbaiki keadaan tersebut dengan mencari makanan.

b. Persepsi, yaitu gambaran seseorang terhadap rangsangan yang masuk melalui panca indranya. Saat seseorang melihat logo merek Apple dan Huawei, maka dia memiliki persepsi yang berbeda terhadap masing-masing merek.

c. Sikap, kondisi suka atau tidak suka seseorang pada kecenderungan dalam evaluasi, perasaan, atau tindakan terhadap sesuatu hal. Berdasarkan pengalamannya terhadap sesuatu, maka sikapnya akan sulit berubah, karena sikap sangat dipengaruhi oleh persepsi. d. Pembelajaran, dalam konteks pemasaran, diartikan sebagai pengetahuan atau kemampuan yang didapatkan dari pengalaman yang dapat merubah perilaku konsumen.

e. Teori konsep diri, yaitu gambaran seseorang terhadap dirinya sendiri. Saat seorang paruh baya memandang dirinya sebagai seorang yang masih muda, maka dia bisa membeli mobil sport dan pakaian yang modis untuk mewujudkan konsep dirinya.

2. Pengaruh dari Lingkungan

a. Budaya, budaya dapat diartikan sebagai nilai, kepercayaan, kesukaan, dan selera yang diturunkan dari satu generasi ke generasi yang lain. Budaya adalah pengaruh yang sangat besar terhadap keputusan pembelian konsumen.

b. Keluarga, pada umumnya, setiap orang adalah bagian dari setidaknya dua keluarga, yaitu keluarga dimana dia lahir dan keluarga yang dia bangun saat dewasa. Anggota keluarga mungkin adalah pengaruh yang paling penting terhadap keputusan pembelian karena tingkat kedekatan dan interaksi yang berkelanjutan. Saat kita membeli sesuatu, tidak jarang faktor keluargalah yang menentukan keputusan pembeliannya.

c. Sosial, sebagai seorang konsumen, kita selalu berada dalam beberapa kelompok sosial, seperti sebuah keluarga, saat di sekolah, mengikuti klub basket, klub bela diri, dan lain sebagainya. Dan setiap kelompok tersebut mempengaruhi keputusan pembelian anggotanya.

\section{Indikator Keputusan Pembelian}

Keputusan pembelian diukur dengan menggunakan indikator-indikator (Kotler dan Keller, 2009) berikut:

1. Pengenalan Masalah

Proses pembelian dimulai ketika pembeli menyadari suatu masalah atau kebutuhan yang dipicu oleh rangsangan internal atau eksternal.

2. Pencarian Informasi

Konsumen sering mencari jumlah informasi yang terbatas.Jumlah dan pengaruh relatif dari sumber-sumber ini bervariasi dengan kategori produk dan karakteristik pembeli.

3. Evaluasi Alternatif 
Konsumen akan memberikan perhatian terbesar pada atribut yang menghantarkan manfaat yang memenuhi kebutuhan. Kita sering dapat mensegmentasikan pasar suatu produk berdasarkan atribut yang penting bagi berbagai kelompok konsumen.

\section{Keputusan Pembelian}

Konsumen membentuk maksud untuk membeli merek yang paling disukai.

5. Perilaku Pasca Pembelian

Setelah pembelian, konsumen mungkin mengalami konflik terhadap fitur yang mengkhawatirkan atau mendengar hal-hal yang menyenangkan tentang merek lain.

\section{METODE PENELITIAN}

\section{Jenis dan Sumber Data}

Jenis data yang digunakan dalam penelitian ini adalah:

1. Data kualitatif yaitu jenis data yang digunakan untuk mendapatkan data yang mendalam yang mengandung makna. Oleh karena itu dalam penelitian kualitatif tidak menekankan pada generalisasi, tetapi lebih menekankan pada makna (Sugiyono, 2008). Dalam penelitian ini, data kualitatif berupa teori-teori dari pendapat ahli dan gambaran umum produk Kinder Joy.

2. Data kuantitatif yaitu jenis data yang berupa angka-angka dan analisis menggunakan statistik (Sugiyono, 2008). Dalam penelitian ini, data kuantitatif berupa hasil skor kuesioner kepada responden yang diklasifikasikan dengan menggunakan Skala Likert (1-5).

Adapun sumber data yang akan digunakan dalam penelitian ini adalah:

1. Data primer yaitu sumber data yang langsung memberikan data kepada pengumpul data (Sugiyono, 2014). Data primer dalam penelitian ini berupa hasil observasi, wawancara, dan penyebaran kuesioner kepada responden.

2. Data sekunder yaitu sumber data yang tidak secara langsung memberikan data kepada pengumpul data, misalnya lewat orang lain atau dokumen (Sugiyono, 2014). Data sekunder dalam penelitian ini berupa artikelartikel jurnal, buku-buku referensi, skripsi dan internet yang ada kaitannya dengan penelitian ini.

\section{Populasi dan Sampel}

Populasi dalam penelitian ini adalah semua masyarakat Kota Langsa yang pernah membeli produk Kinder Joy yang tidak diketahui jumlahnya secara pasti.Teknik pengambilan sampel yang digunakan dalam penelitian ini adalah Non Probability Sampling, yaitu teknik pengambilan sampel yang tidak memberi peluang yang sama bagi setiap anggota populasi untuk dipilih sebagai sampel, dan jenis teknik sampling insidental, yaitu teknik penentuan sampel berdasarkan siapa saja yang secara kebetulan bertemu dengan peneliti, jika yang bersangkutan cocok dengan sumber data (Sugiyono, 2008).

Sedangkan populasi pada penelitian ini adalah unknown population (populasi yang tidak diketahui jumlahnya). Sarwono (2011) menjelaskan bahwa untuk menentukan jumlah sampel dalam penelitian yang seperti ini, maka digunakan rumus Cochran sebagai berikut:

$\mathrm{n}_{0}=\frac{z^{2} \cdot \mathrm{p} \cdot \mathrm{q}}{\mathrm{e}^{2}}$

Keterangan:

$\mathrm{n}_{0}=$ ukuran sampel

$\mathrm{Z}^{2}=$ abscissa kurva normal yang memotong area sisi (tails) atau 1-tingkat kepercayaan, misalnya sebesar $95 \%=$ 1.96

$\mathrm{e}=$ tingkat kepercayaan yang diinginkan

$\mathrm{p}=$ Proporsi yang diestimasi suatu atribut yang ada dalam suatu populasi

$\mathrm{q}=1-\mathrm{p}$

Maka dengan rumus tersebut, jumlah sampel pada penelitian ini adalah 96 orang responden. Dengan perhitungan sebagai berikut:

$$
\begin{aligned}
& \mathrm{n}_{0}=\frac{z^{2} \cdot \mathrm{p} \cdot \mathrm{q}}{\mathrm{e}^{2}} \\
& \mathrm{n}_{0}=\frac{\left(1,96^{2}\right)(0,5)(0,5)}{0,1^{2}} \\
& \mathrm{n}_{0}=\frac{3,8416 \cdot 0,25}{0,01} \\
& \mathrm{n}_{0}=96,04
\end{aligned}
$$

\section{Metode Pengumpulan Data}

Untuk mendapatkan informasi yang diperlukan dalam penelitian ini, maka 
penulisan melakukan metode pengumpulan data sebagai berikut.

1. Penelitian Lapangan (Field Research)

a. Observasi merupakan suatu proses yang kompleks, yang tersusun dari berbagai proses biologis dan psikologis. Dua di antara yang terpenting adalah proses-proses pengamatan dan ingatan (Sutrisno Hadi dalam Sugiyono, 2014). Observasi dalam penelitian ini berupa mengamati secara langsung konsumen produk Kinder Joy.

b. Wawancara, wawancara dilakukan sebagai teknik pengumpulan data, apabila peneliti ingin melakukan studi pendahuluan untuk menemukan permasalahan yang harus diteliti, dan juga apabila peneliti ingin mengetahui hal-hal yang lebih mendalam (Sugiyono, 2008). Dalam wawancara ini peneliti melakukan wawancara kepada konsumen produk Kinder Joy di Kota Langsa untuk menggali informasi yang dapat membantu meningkatkan hasil dari penelitian ini.

c. Kuesioner, menurut Sugiyono (2014), kuesioner dapat berupa pertanyaanpertanyaan tertutup atau terbuka, dapat diberikan kepada responden secara langsung atau dikirim melalui pos atau internet. Kuesioner dalam penelitian ini disebarkan kepada responden produk Kinder Joy di Kota Langsa dengan menggunakan Skala Likert. Skala Likert digunakan untuk mengukur sikap, pendapat, dan persepsi seseorang atau sekelompok orang tentang fenomena sosial (Sugiyono, 2014).

2. Penelitian Kepustakaan (Library Research)

Penelitian kepustakaan berkaitan dengan kajian teoritis dan referensi lain yang terkait dengan nilai, budaya, dan norma yang berkembang pada situasi sosial yang diteliti (Sugiyono, 2008). Penelitian kepustakaan dalam penelitian ini berupa, buku-buku referensi, artikel-artikel jurnal, skripsi, dan internet yang ada kaitannya dengan penelitian ini.

\section{Metode Analisis Data}

Metode yang digunakan dalam menganalisa data yang diperoleh dari lapangan dengan menggunakan program IBM SPSS (Statistical Package For Social Sciences)Versi 23 adalah analisis regresi linear berganda yang dikemukakan oleh Sugiyono (2009):

$$
\mathrm{Y}=\mathrm{a}+\mathrm{b}_{1} \mathrm{X}_{1}+\mathrm{b}_{2} \mathrm{X}_{2}
$$

Dimana:

$\mathrm{Y} \quad=$ Variabel Terikat

a $\quad=$ Konstanta

$b_{1}, b_{2}=$ Koefisien Variabel-Variabel bebas

$\mathrm{X}_{1}, \mathrm{X}_{2}=$ Variabel-Variabel bebas

Untuk kebutuhan penelitian maka rumus tersebut dapat dimodifikasi menjadi:

$$
\mathrm{KP}=\mathrm{a}+\mathrm{bLH}+\mathrm{bBDK}
$$

Dimana:

KP = Keputusan Pembelian

$\mathrm{a} \quad=$ Konstanta

$\mathrm{b}_{1} \quad=$ Koefisien Label Halal

$\mathrm{b}_{2} \quad=$ Koefisien Bonus Dalam Kemasan

LH = Label Halal

BDK = Bonus Dalam Kemasan

\section{HASIL ANALISIS}

Pengaruh Label Halal dan Bonus dalam Kemasan Terhadap Keputusan Pembelian

Pengaruh label halal dan bonus dalam kemasan terhadap keputusan pembelian pada produk Kinder Joy pada masyarakat Kota Langsa dapat diketahui dari data primer penelitian yang diolah dengan program SPSS (Statistical Package For Social Sciences) Versi 23. Berdasarkan Tabel 1dapat dibuat persamaan sebagai berikut:

$$
\mathrm{KP}=3,254+0,474 \mathrm{LH}+0,728 \mathrm{BDK}
$$

Berdasarkan persamaan di atas dapat dijelaskan:

1. Nilai a atau konstanta sebesar 3,254 adalah nilai variabel keputusan pembelian 
jika variabel bebas (label halal dan bonus dalam kemasan) bernilai nol.

2. Koefisien regresi variabel label halal sebesar 0,474 menunjukkan pengaruh positif terhadap keputusan pembelian produk Kinder Joy dan jika ditingkatkan sebesar satu satuan maka akan meningkatkan keputusan pembelian produk Kinder Joy sebesar 0,474 dengan asumsi variabel bonus dalam kemasan tetap.

3. Koefisien regresi variabel bonus dalam kemasan sebesar 0,728 menunjukkan

Tabel 1. Hasil Analisis Statistik

\begin{tabular}{lccc}
\hline Variabel & B & t & Sig. t \\
\hline Konstanta & 3,254 & 2,588 & 0,011 \\
Label Halal & 0,474 & 10,628 & 0,000 \\
Bonus Dalam Kemasan & 0,728 & 8,532 & 0,000 \\
\hline R. Square & $=0,657$ & & \\
F & $=88,958$ & & \\
Sig. F & $=0,000$ & & \\
\hline
\end{tabular}

Sumber: Data Primer diolah, 2017

pengaruh positif terhadap keputusan pembelian produk Kinder Joy dan jika ditingkatkan sebesar satu satuan maka akan meningkatkan keputusan pembelian produk Kinder Joy sebesar 0,728 dengan asumsi variabel label halal tetap.

\section{Koefisien Determinasi $\left(\mathbf{R}^{\mathbf{2}}\right)$}

Berdasarkan Tabel 1 dapat diketahui bahwa nilai koefisien determinasi $\left(\mathrm{R}^{2}\right)$ pada kolom $\mathrm{R}$ square sebesar 0,657 (65,7\%) yang dapat dinyatakan bahwa variabel label halal dan bonus dalam kemasan memberikan pengaruh terhadap variabel keputusan pembelian produk Kinder Joy sebesar 65,7\%, dan sisanya $34,3 \%$ dipengaruhi oleh variabelvariabel lain yang tidak diteliti dalam penelitian ini.

\section{Pembuktian Hipotesis}

Pembuktian hipotesis dalam penelitian ini menggunakan uji statistik yang terdiri dari uji t dan uji F.

1. Uji t (Uji Parsial)

Untuk mengetahui atau menguji pengaruh label halal dan bonus dalam kemasan terhadap keputusan pembelian produk kinder joy pada masyarakat Kota Langsa maka dapat dijelaskan berdasarkan Tabel 1. sebagai berikut:

a. Label Halal
Nilai $t_{\text {hitung variabel label halal sebesar }}$ 10,628 sementara itu nilai pada $t_{\text {tabel }} \mathrm{db}$ $=\mathrm{n}-\mathrm{k}$ (96-3) pada taraf signifikan 0,05 sebesar 1,661, maka thitung 10,628 > $\mathrm{t}_{\text {tabel }} 1,661$ dan nilai signifikansi $(0,000$ $<0,05)$ artinya variabel label halal berpengaruh signifikan terhadap keputusan pembelian produk Kinder Joy pada masyarakat Kota Langsa, maka hipotesis diterima.

Hasil penelitian ini sesuai dengan penelitian sebelumnya yang dilakukan oleh Utami (2013) dimana hasil penelitiannya yaitu variabel label halal berpengaruh signifikan terhadap keputusan pembelian dengan nilai $t_{\text {hitung }}$ sebesar 8,385.

b. Bonus dalam Kemasan

Nilai $t_{\text {hitung }}$ variabel bonus dalam kemasan sebesar 8,532 sementara itu nilai pada $t_{\text {tabel }} d b=n-k(96-3)$ pada taraf signifikan 0,05 sebesar 1,661, maka $t_{\text {hitung }} 8,532>t_{\text {tabel }} 1,661$ dan nilai signifikansi $(0,000<0,05)$ artinya variabel bonus dalam kemasan berpengaruh signifikan terhadap keputusan pembelian produk Kinder Joy pada masyarakat Kota Langsa, maka hipotesis diterima.

Hasil penelitian ini sesuai dengan penelitian sebelumnya yang dilakukan oleh Awaliyah (2010) dimana hasil penelitiannya yaitu variabel bonus 
dalam kemasan berpengaruh signifikan terhadap keputusan pembelian dengan nilai $t_{\text {hitung }}$ sebesar 2,311.

2. Uji F (Simultan)

Berdasarkan hasil uji $F$ atau uji simultan dari Tabel 1.ditunjukkan bahwa $F_{\text {hitung }}$ sebesar 88,958 sedangkan $F_{\text {tabel }} \mathrm{df}_{1}$ $=\mathrm{k}-1$ (3-1) dan $\mathrm{df}_{2}=\mathrm{n}-\mathrm{k}$ (96-3) dengan tingkat signifikan 0,05 adalah 3,09. Hasil ini berarti $F_{\text {hitung }}>F_{\text {tabel }}(88,958>3,09)$, maka dapat dinyatakan secara statistik variabel label halal dan bonus dalam kemasan berpengaruh signifikan terhadap keputusan pembelian produk Kinder Joy pada masyarakat Kota Langsa. Dengan demikian hipotesis dalam penelitian ini dapat diterima.

\section{KESIMPULAN DAN SARAN Kesimpulan}

Dari hasil penelitian dan pembahasan yang telah dilakukan, maka ditarik kesimpulan yang dapat dikemukakan sebagai berikut:

1. Hasil persamaan regresi linear berganda diketahui bahwa label halal dan bonus dalam kemasan berpengaruh positif terhadap keputusan pembelian produk Kinder Joy pada masyarakat Kota Langsa.

2. Hasil koefisien determinasi $\left(\mathrm{R}^{2}\right)$ yang diperoleh pada kolom $\mathrm{R}$ Square sebesar $0,657(65,7 \%)$ yang dapat dinyatakan bahwa variabel label halal dan bonus dalam kemasan memberikan pengaruh terhadap variabel keputusan pembelian produk Kinder Joy sebesar $65,7 \%$ dan sisanya $34,3 \%$ dipengaruhi variabelvariabel lain yang tidak diteliti dalam penelitian ini.

3. Hasil uji t diperoleh pada variabel label halal berpengaruh signifikan terhadap keputusan pembelian dan bonus dalam kemasan berpengaruh signifikan terhadap keputusan pembelian produk Kinder Joy pada masyarakat Kota Langsa.

4. Hasil uji $F$ diketahui bahwa secara simultan atau bersama-sama label halal dan bonus dalam kemasan berpengaruh signifikan terhadap keputusan pembelian produk Kinder Joy pada masyarakat Kota Langsa.

\section{Saran}

Berdasarkan hasil penelitian dan kesimpulan maka dapat diberikan beberapa saran, sebagai berikut:

1. Untuk pihak perusahaan hendaknya lebih mempertimbangkan aspek-aspek yang menyangkut keputusan pembelian seperti yang dibahas dalam penelitian ini yaitu label halal dan bonus dalam kemasan, karena menurut hasil penelitian kedua variabel tersebut berpengaruh positif dan signifikan terhadap keputusan pembelian konsumen.

2. Untuk pihak produsen hendaknya selalu mengedepankan label halal dengan mencantumkan label halal kedalam kemasan agar memberikan nilai lebih dan menumbuhkan minat beli bagi konsumen muslim dalam memilih dan membeli produk Kinder Joy, dan memberikan bonus dalam kemasan tidak hanya untuk konsumen anak-anak seperti mainan gratis, namun juga kepada konsumen dewasa seperti memberikan bonus produk Kinder Joy secara gratis jika membeli dengan jumlah pembelian tertentu dari produk-produk yang dijual agar terjadi peningkatan terhadap keputusan pembelian dari para konsumen.

3. Untuk pihak lain yang akan melakukan penelitian selanjutnya hendaknya variabel yang diteliti tidak hanya sebatas label halal dan bonus dalam kemasan saja, karena masih banyak faktor-faktor lain yang dapat mempengaruhi keputusan pembelian, seperti harga, kualitas produk, dan lain-lain.

\section{DAFTAR PUSTAKA}

Ath-Thawil, A. 2016. Syubhat Membuat Galau. Solo: Tinta Medina.

Awaliyah, R. F. 2010.Analisis Pengaruh Persepsi Konsumen dan Bonus dalam Kemasan terhadap Keputusan Pembelian. Skripsi. UIN Syarif Hidayatullah Jakarta. 
Boone, L. E. dan Kurtz, D. L. 2010.Contemporary Marketing $\mathbf{1 4}^{\text {th }}$ Edition. Canada: South Western.

Bulan, T. P. L., \& Rizal, muhammad. (2016). Pengaruh Labelisasi Halal terhadap Keputusan Pembelian Sosis di Kuala Simpang Kabupaten Aceh Tamiang. Jurnal Manajemen \& Keuangan, 5(1), 431-439. Retrieved from http://ejurnalunsam.id/index.php/jmk/art icle/view/49

Sarwono, J. 2011.C ara Menggabung Riset Kuantitatif dan Riset Kualitatif Secara Benar. Jakarta: Penerbit PT Elex Media Komputindo.

Kotler, P.dan Armstrong, G. 2008. PrinsipPrinsip Pemasaran Edisi 12 Jilid 1. Jakarta: Penerbit Erlangga. , dan Keller, K. L. 2009. Manajemen

Pemasaran. Jakarta: Penerbit Erlangga.

Prihastama, B. V. 2016. Pengaruh Price

Discount dan Bonus Pack terhadap Impulse Buying pada Pelanggan Minimarket (Studi pada Pelanggan Minimarket Indomaret Jl. Demangan Baru, Depok, Sleman, Yogyakarta).
Skripsi. Universitas Negeri Yogyakarta.

PP No. 69 Tahun 1999 Tentang Label dan Iklan Pangan.

Sugiyono. 2008. Metode Penelitian Bisnis. Bandung: Alfabeta.

2014. Metode Penelitian Kuantitatif, Kualitatif, dan R\&D, Bandung: Alfabeta.

Utami, W. B. 2013. Pengaruh Label Halal terhadap Keputusan Membeli (Survei pada Pembeli Produk Kosmetik Wardah di Outlet Wardah Griya Muslim Annisa Yogyakarta). Skripsi. Universitas Islam Negeri Sunan Kalijaga.

UU No. 33 Tahun 2014 Tentang Jaminan Produk Halal.

www.halalmui.org/mui14/index.php/main/go _to-section/56/1362/page/1. Maret 2017.

www.khazanah.republika.co.id/berita/duniaislam/islamnusantara/16/10/06/oemke0396-bagiumat-islam-sertifikasi-halal-adalahperlindungan, 6 Oktober 2016.

www.kinder.me/en/kinder-joy. 25 Februari 2017. 